\title{
An unusual distended abdomen
}

\author{
Declan McDonnell, ${ }^{1}$ Luigi Bombieri ${ }^{2}$
}

${ }^{1}$ King's College London, London, UK

${ }^{2}$ Department of Obstetrics and Gynaecology, Derriford Hospital, Plymouth, UK

\section{Correspondence to} Dr Declan McDonnell, declan@doctors.org.uk

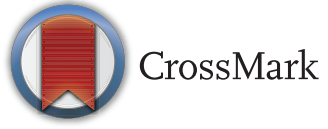

To cite: McDonnell D, Bombieri L. BMJ Case Rep Published online: [please include Day Month Year] doi:10.1136/bcr-2013202168

\section{DESCRIPTION}

An otherwise fit and healthy woman in her early thirties presented 4 days after an elective uncomplicated caesarean section reporting of colicky abdominal pain and marked distension over the past $24 \mathrm{~h}$. The patient vomited several times over this period, but continued to pass flatus and liquid stool. She had also passed several large clots per vaginum, and did not report any urinary disturbance. Endometritis was considered on history alone, but a firm and tender abdomen, coupled with colicky pain and a history of vomiting made the team suspicious of an incomplete bowel obstruction. An abdominal radiograph was sought to look for evidence of this condition (figure 1). The image shows a large mass in the abdomen, consistent with

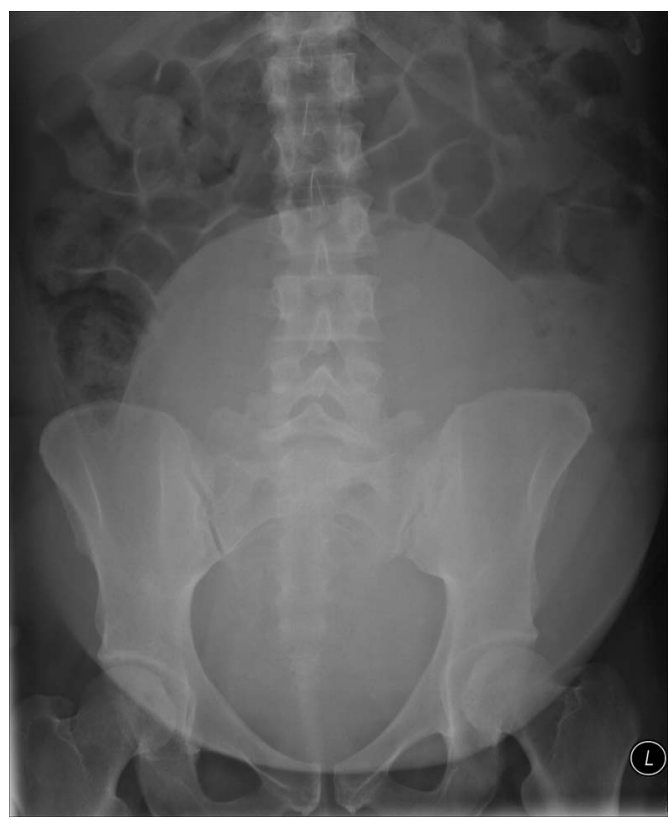

Figure 1 An abdominal radiograph showing a massive distended bladder. massive bladder distension. A catheter was placed and over $3500 \mathrm{~mL}$ of urine was drained from organ to provide immediate symptomatic relief. The patient was found to have significant faecal impaction in the rectum which would have compressed the bladder outflow and caused the massive urinary retention. It also affected drainage of the uterus and led to retention of clots, which were later expelled by compression from the distending bladder. The patient had continued to micturate due to overflow incontinence. The impaction was treated by osmotic laxatives and phosphate enemas, and the patient was discharged after 2 days. Follow-up was arranged for the following week at the urogynaecology clinic, whereby it was found she had made good progress as her bladder function had returned to normal.

\section{Learning points}

- The pelvis contains many important structures which can have a significant impact on surrounding viscera when one of these fails to work correctly.

- Never assume that surgical complications can only arise from regions directly involved in that procedure. Endometritis is one of the most common complications following caesarean delivery, but as it is an abdominal operation, any structure within the abdomen or pelvis can be affected.

- Overflow incontinence can mask bladder outflow obstruction.

\section{Competing interests None.}

Patient consent Obtained.

Provenance and peer review Not commissioned; externally peer reviewed.

\footnotetext{
Copyright 2013 BMJ Publishing Group. All rights reserved. For permission to reuse any of this content visit http://group.bmj.com/group/rights-licensing/permissions.

BMJ Case Report Fellows may re-use this article for personal use and teaching without any further permission.

Become a Fellow of BMJ Case Reports today and you can:

- Submit as many cases as you like

- Enjoy fast sympathetic peer review and rapid publication of accepted articles

- Access all the published articles

- Re-use any of the published material for personal use and teaching without further permission

For information on Institutional Fellowships contact consortiasales@bmjgroup.com

Visit casereports.bmj.com for more articles like this and to become a Fellow
} 